\title{
Effects of the Technology Development, Socioeconomic Status, Career Information, and Learning Process on the Career Aspiration of Vocational High School Students
}

\author{
Ari Dwi Nur Indriawan Musyono ${ }^{1}$, and Soenarto ${ }^{2}$ \\ ${ }^{1}$ Mechanical Engineering Education, Semarang State University, Indonesia \\ ${ }^{2}$ Vocational Education, Yogyakarta State University, Indonesia \\ ari.kecil@mail.unnes.ac.id, soenarto@uny.ac.id
}

Keywords: Career aspiration, technology development, socio-economic status, career information, learning process.

Abstract: This study aims to investigate: (1) the effect of the technology development on the career aspiration of vocational high school (VHS) students in Kebumen Regency, (2) the effect of the socio-economic status on their career aspiration, (3) the effect of the career information on their career inspiration, (4) the effect of the learning process on their career inspiration, and (5) the effects of the technology development, socioeconomic status, career information, and learning process at school on their career aspiration. This was an ex post facto study. The research population comprised all Grade XI students of state VHSs in Kebumen Regency with a total of 2375 students. The sample was selected by the Krejcie and Morgan formula, and the sample size in proportion to the population at an error level of 5\% was 331 students. The data were collected through a questionnaire and documentation. The instrument validity was assessed in terms of content validity and construct validity. The instrument reliability was assessed by the Cronbach Alpha formula. The data were analyzed by means of the descriptive technique, simple regression, and multiple regression. The results of the study are as follows. (1) The technology development has an effect on the career aspiration of VHS students in Kebumen Regency with a contribution of $18.4 \%$. (2) The socioeconomic status has an effect on their career aspiration with a contribution of $2 \%$. (3) The career information has an effect on their career aspiration with a contribution of $22.3 \%$. (4) The learning process has an effect on their career aspiration with a contribution of $17.4 \%$. (5) The technology development, socio-economic status, career information, and learning process as an aggregate have effects on their career aspiration with a contribution of $31.9 \%$.

\section{INTRODUCTION}

Education is currently experiencing rapid changes that continue to be adapted to the demands of the workforce needs in the world, such as science and technology and increasingly modern forms of learning. This development has been anticipated by the education world in Indonesia, one of which is making changes in the curriculum, but curriculum changes are not always a definite solution to the changes that occur.

The development of life and technology that is increasingly fast demands changes to be able to follow it. The mastery of science and technology is needed to support these changes and developments. Developments that occur not only affect the world of education but also affect the business world and the industrial world. The mastery of industrial technology is increasingly used to be able to create products and better quality and human resources are important factors that are required to master the technology so that it can be used optimally.

Schools as one of the educational institutions that process the nation's successors are required to be able to adjust changes and developments that occur. Vocational High Schools (VHSs) that are part of the national education system have a goal in producing competent skilled workers and in accordance with the needs of the workforce and the industrial world. So, it cannot be denied that the world of work today increasingly needs competent workers ready for work. Competence is a benchmark for the quality of graduates of educational products produced, therefore there is a need for teaching and learning processes that can improve graduate competencies.

Students as prospective workers are indirectly formed from the teaching and learning process carried out in and outside the classroom. The 
development of science and attitudes as interaction activities between teachers and students will provide provisions and good experience in getting sufficient competence to meet the needs of the workforce. But this process is sometimes not always satisfying and well implemented. Educators sometimes forget about the development of technology and career information in giving views to students what they are facing, so that it will have an impact on students who feel unable to compete and can make students choose careers that are not in accordance with their competencies.

Vocational High Schools (VHS) are institutions that aim to prepare qualified students to be able to work in certain fields. To produce quality students, the teacher needs to provide material that is in accordance with the objectives to be achieved. This is consistent with the opinion of Prosser \& Quigley (1950), that: (1) Effective vocational education can only be given where training tasks are carried out in the same manner, tools and machinery as determined in the workplace, and (2) Vocational education will be effective if it trains a person in the habits of thinking and working as required in the work itself. This condition is expected to create VHS graduates who have competencies according to the needs of the workforce.

Samsudi in his 43rd Semarang State University Anniversary speech on March 31, 2008, said that ideally, nationally VHS graduates could directly enter the workforce around $80-85 \%$, while so far only $61 \%$ of VHS graduates had been absorbed (Merdeka.com, 2008). More dilemma again 61\% of the vocational graduates do not all work in accordance with the majors that were occupied during school. This is due to several factors including (1) lack of work readiness from vocational graduates; (2) the absence of good cooperation between VHSs and the world of work; (3) VHSs have not been identified by the workforce needs; and (4) lack of attention to the potential in the area.

The discrepancy of vocational graduates working is also strengthened by Wartanto (Administrator, 2012) Director General of PAUDNI DirectorGeneral said that "At present many graduates are working not in accordance with their educational background, for example, there are automotive graduates working in hotels, culinary graduates working in banks "This is what we will change, how graduates from this vocational education institution can directly work according to their educational background". Seeing these conditions raises the assumption that the work obtained by vocational graduates is not in accordance with the career aspirations of students when attending school.

Inadequate career selection by students basically has minimized the school by holding career guidance. Career guidance is a self-development activity in an effort to make students' character and personality in accordance with the development of science and technology and environmental conditions. Developments that occur may have a direct impact on students' career aspirations, so students can achieve expectations of their career aspirations without having to be undermined by rapid development.

Career aspirations are one of the things that can support the careers expected by students. According to Mubarok (2012, p.50) revealed that: career aspirations are very important to support the future career of students because it is a demand in life. According to Quaglia and Cobb (1996, p.130) "aspirations can be defined as a student's ability to identify and set goals for the future, while being inspired in the present to work towards those goals" which means that aspiration can be defined as an individual's ability to identify and set future goals, which are inspired by the information obtained today towards his career goals. Aspiration is a realistic desire, hope, and ideal of the individual towards achievement in the future, where the desire is something that will be endeavoured to achieve.

The achievement of a person's aspirations is influenced by the reality that is how a person sets his aspirations based on the existing reality. So the higher the difficulty level, the higher the individual's desire to achieve it. High and low aspirations of someone influenced by factors originating from individuals and factors originating from the environment (Hurlock, 1973). Factors from within individuals such as intelligence, gender, interests, values, and competition. Factors originating from the environment are external factors originating from outside the individual such as the ambitions of parents, the influence of expectations of important people, family, birth order, culture, past experience, and group expectations

A child in building his future hopes starts from the family environment. Interaction between family members can influence a child in making career decisions in the future. Each family with its socioeconomic status presents a different way of giving children the opportunity to develop their talents and abilities. According to Juminardi (2013, p.1) where a person's socioeconomic conditions tend to be a reference in determining their status in society, in general, the socio-economic life of a 
factors such as the development of industrial technology, socioeconomic status, career information, and learning processes can influence it. Based on the important description to examine the Effect of Technology Development, Career Information and Learning Processes on the Aspirations of Vocational High School Students in Kebumen Regency.

\section{RESEARCH METHODS} existing aspirations are affected by career information and learning processes at school. Career information received by students can act as a tool that can help in understanding the world of work that will be faced.

The mismatch of career information received by students plays a role in both strengthening and weakening student career aspirations. Shertzer (1974, p.32) argues that information about the job must be valid and the data can be used to consider the position and function of the job, duties, and obligations in the job, including the pre-conditions, conditions, and rewards offered by the job. Therefore, the ability of students to prepare themselves to achieve their career aspirations should be supported by a good learning process at school. A good learning process will result in changes in knowledge, understanding, skills and attitude values in students.

Related to the absorption of VHS graduates who are already working, Kebumen Regency is proud to declare it as a Vocational Regency. This is not excessive because there are more VHS students than high school students who are divided into 26 areas of expertise in 61 public and private vocational high schools (VHS) in the district. The Declaration of the Vocational Regency with the theme "Together with VHS We Realize the Independence of Industrial and Economic Technology Towards Advanced and Prosperous Kebumen" was carried out directly by the Kebumen Regent. In 2011 according to the Head of the Youth and Sports Education Office (Dikpora) Kebumen district, there were $68 \%$ of VHS graduates absorbed by the world of work. (Kebumen.info News, 2012). Based on interviews with several VHS teachers in Kebumen district, it was revealed that the absorption of students in the world of work is not entirely in accordance with the competency of students' expertise, but the school does not have statistical data on this discrepancy.

Knowing the extent of career aspirations possessed by students with growing development, it is necessary to further search about career aspirations owned by students and find out whether
This type of research is an ex post facto research using a quantitative approach and was carried out in the State VHS in Kebumen District as many as seven schools namely VHS 1 Kebumen, VHS 2 Kebumen, VHS 1 Gombong, VHS 1 Karanganyar, VHS 1 Ambal, VHS 1 Karanggayam, and VHS 1 Puring.

The population in this study was the students of class XI VHS in Kebumen Regency. The selection of class XI as a population is because class XI should be able to determine career decisions based on the stages of career decision making. Samples are taken by cluster random sampling, where this technique is used because the object to be studied or data sources are very broad (Sugiyono, 2010, p.121).

The steps of sampling using a cluster random sampling through two stages, namely in the first stage selecting sample class XI in each VHS in accordance with the expertise program in which the class is chosen randomly so that each expertise program is represented. Then the second step is to choose students randomly in the selected class in accordance with a predetermined number. Determination of student samples using the formula Krejcie and Morgan with a 95\% confidence level. For a population of 2375 students from seven State VHSs in Kebumen, a sample of 331 students was obtained. The number of samples can be seen in Table 1.

Table 1. Population and Research Samples

\begin{tabular}{clcc}
\hline No. & \multicolumn{1}{c}{ School } & Population & Samples \\
\hline 1. & VHS 1 Kebumen & 421 & 59 \\
2. & VHS 2 Kebumen & 506 & 71 \\
3. & VHS 1 Gombong & 350 & 49 \\
4. & VHS 1 Karanganyar & 360 & 50 \\
5. & VHS 1 Ambal & 246 & 34 \\
6. & VHS 1 Karanggayam & 145 & 20 \\
7. & VHS 1 Puring & 347 & 48 \\
& Total students & $\mathbf{2 3 7 5}$ & $\mathbf{3 3 1}$ \\
\hline
\end{tabular}


Data collection techniques in this study were conducted using questionnaire and documentation methods. The questionnaire consisted of 81 structured statement items representing indicators of career aspiration variables, technological development, career information, and the learning process. Statement items are measured using a Likert scale with four alternative answers. The answers to each statement are compiled from gradations so that they do not match what can be seen in Table 2.

Table 2. Alternative Answer Questionnaire

\begin{tabular}{lc}
\multicolumn{1}{c}{ Scale Answer } & Rating \\
\hline Very appropriate & 4 \\
Corresponding & 3 \\
Not suitable & 2 \\
Unsuitable & 1 \\
\hline
\end{tabular}

The validity of the instruments used in this study was content validity and construct validity. The content validity test is the accuracy of the instrument which measures all items covering all aspects measured. The content validation process is done by making a grid and asking for the consideration of experts who are competent in their fields (expert judgment).

After obtaining expert input and improving it, a field trial is then conducted to assess the construct validity. Trials were conducted on respondents as many as 32 students outside the study sample. The construct validity test is done by correlating the item scores to the total scores using the product-moment correlation formula. The correlation coefficient $\left(r_{x y}\right)$ obtained is then viewed to determine valid items by criteria: if $r_{x y}>0.349$ then the factor or item is valid. Invalid items are subsequently aborted and not included in further analysis.

The results of the calculation of the reliability of the instrument in this study with Alpha Cronbach. If $r_{\text {count }}>r_{\text {table, }}$, it can be concluded that the research instrument is declared reliable (reliable) to be used as a measurement tool. Full results can be seen in Table 3 .

Tabel 3. Instrument Reliability

\begin{tabular}{clcr}
\hline No. & \multicolumn{1}{c}{ Variable } & NilaiAlpha $(\boldsymbol{\alpha})$ & $\mathrm{r}_{\text {tabel }}$ \\
\hline 1. & Career Aspirations & 0,904 & 0,349 \\
2. & Technological & 0,596 & 0,349 \\
& development & 0,356 & 0,349 \\
3. & Socio-Economic Status & 0,972 & 0,349 \\
4. & Career Information & 0,885 & 0,349 \\
5. & Learning process & & \\
\hline
\end{tabular}

Table 3 shows that the existing variables have alpha coefficients which can be concluded that the research instruments for the five variables are declared reliable because $r_{\text {count }}>r_{\text {table. Data analysis }}$ techniques used to answer research questions are descriptive and inferential analysis.

\section{RESEARCH RESULTS AND DISCUSSION}

\subsection{Characteristics of Respondents}

Before presenting data on the results of each study in this study, the characteristics of respondents are briefly described. These characteristics include expertise programs, gender, parents' socioeconomic status and career aspirations of students.

The distribution of respondents based on the respondent's expertise program consisted of 18 expertise programs from 7 State VHSs in Kebumen Regency. Which can be seen in table 4 where the expertise program that has the highest number of respondents is Light Vehicle Engineering, this is due to the high interest of students in the automotive world such as studying motor engines.

Table 4. Respondents according to the Expertise Program

\begin{tabular}{clc}
\hline No. & \multicolumn{1}{c}{ Expertise Program } & Respondent \\
\hline 1. & Software Engineering & 10 \\
2. & Multimedia & 10 \\
3. & Office Administration & 29 \\
4. & Accounting & 37 \\
5. & Business Administration & 23 \\
6. & Marketing & 20 \\
7. & Audio Video Technique & 8 \\
8. & Electric Power Installation & 8 \\
9. & Technique & \\
Concrete Stone Construction & 13 \\
10. & Lechniques & 65 \\
11. & Automotive Engineering & 15 \\
12. & Mechanical Engineering & 28 \\
13. & Computer \& Network & 16 \\
14. & Engineering & Catering \\
15. & Fashion & 11 \\
16. & Nautika Ship Commerce & 8 \\
17. & Nautical Fishing Boat & 10 \\
18. & Fishing Boat Techniques & 8 \\
& $\quad$ Total & 12 \\
\hline
\end{tabular}

Meanwhile, if you look at the distribution of respondents by sex, it shows a balanced number of 
respondents, as shown in table 5. This is due to the establishment of expertise programs that are of interest to women such as Food, Fashion and Business Administration.

Table 5. Respondents by Gender

\begin{tabular}{clcc}
\hline No & Gender & Respondent & $(\boldsymbol{\%})$ \\
\hline 1. & Male & 173 & 52,3 \\
2. & Female & 158 & 47,7 \\
& Total & $\mathbf{3 3 1}$ & $\mathbf{1 0 0}$ \\
\hline
\end{tabular}

\subsection{Description of Research Variables}

\subsubsection{Technological development}

The attitude of students in addressing current technological developments is included in the very high category, as shown in Figure 1, which means the ability of students to understand technological developments is getting better.

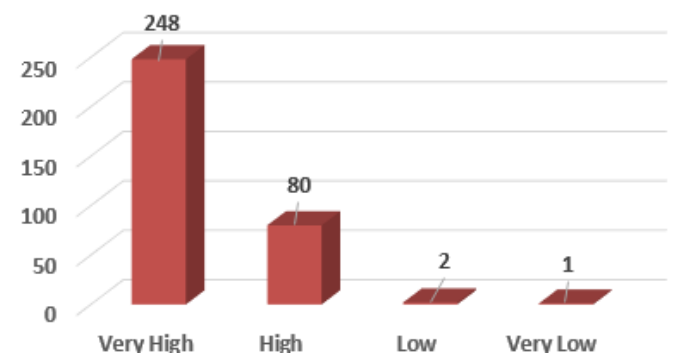

Figure 1. Histogram Graph of Technology Development Variables

\subsubsection{Socio-Economic Status}

Categorizing the background conditions of students' socioeconomic status shows the results as shown in Figure 2. Where these results indicate if the results seem high, then the student is more established social status.

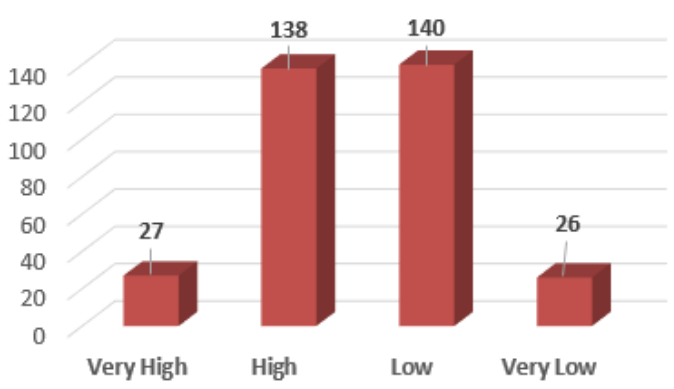

Figure 2. Histogram Graph of Socio-Economic Status Variables

Distribution of respondents based on the socioeconomic status of parents is divided into two parts, namely according to occupation and educational background of parents. Based on the results of the study, there are 9 types of educational background work such as in table 8 and table 9 .

Table 8. Distribution of Respondents by Parent's Occupation

\begin{tabular}{clcc}
\hline No & $\begin{array}{c}\text { Parent Occupation } \\
\text { Amount }\end{array}$ & Respondent & \% \\
\hline 1. & PNS & 13 & 4,33 \\
2. & Employes & 15 & 5,00 \\
3. & Village Aparature & 4 & 1,33 \\
4. & Farmer & 102 & 34,00 \\
5. & Labour & 114 & 38,00 \\
6. & Trade & 19 & 6,33 \\
7. & BUMN & 2 & 0,67 \\
8. & Enterpreneur & 29 & 9,67 \\
9. & Fisherman & 2 & 0,67 \\
& Total & $\mathbf{3 0 0}$ & $\mathbf{1 0 0}$ \\
\hline
\end{tabular}

Table 8 shows the number of distributions according to parents' work, where the results show that the work of parents of students is dominated by farmers (34\%) and laborers (38\%). This shows the compatibility between work and environmental conditions in Kebumen Regency which is mostly dominated by agricultural land

Table 9. Distribution of Respondents by Educational Background of Parents

\begin{tabular}{clccc}
\hline No & Education & Father & Mother & \% \\
\hline 1. & College & 9 & 7 & 2,45 \\
2. & $\begin{array}{l}\text { Senior High } \\
\text { School }\end{array}$ & 76 & 57 & 20,40 \\
3. & $\begin{array}{l}\text { Junior High } \\
\text { School }\end{array}$ & 64 & 65 & 19,79 \\
4. & $\begin{array}{l}\text { Elementary } \\
\text { School }\end{array}$ & 178 & 196 & 57,36 \\
& $\quad$ Total & $\mathbf{3 2 7}$ & $\mathbf{3 2 5}$ & $\mathbf{1 0 0}$ \\
\hline
\end{tabular}

Looking at the condition of the distribution of respondents based on parents' educational background, it can be seen in Table 9 that the educational background is dominated by elementary/equivalent level. This could be one of the reasons why most of the work of parents is farmers or laborers.

\subsubsection{Career Information}

The condition of students in responding to the condition of the career information they read can be seen in the histogram graph in Figure 3, where the 
social status who are able to choose to continue to a

results of the category are higher the better the career information that is read.

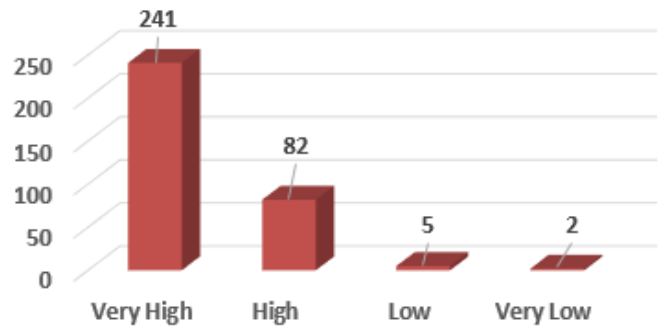

Figure 3. Histogram Graph of Career Information Variables

\subsubsection{Learning Process}

The condition of students in assessing the learning process they feel can be seen in the histogram graph in Figure 4 which shows very high results, this shows the good process that occurred.

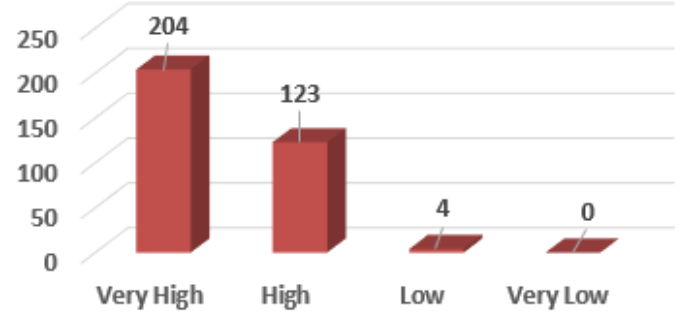

Figure 4. Learning Process Variable Histogram Graph

\subsubsection{Career Aspirations of VHS Students in Kebumen Regency}

Looking at the distribution of respondents based on career aspirations will look at a decision when students graduate. The researcher provides three alternative answers. A description of students' career decisions can be seen in Table 12 .

Table 12. Distribution of Respondents according to Student Career Aspirations

\begin{tabular}{clcc}
\hline No & Career Aspirations & Respondent & $(\boldsymbol{\%})$ \\
\hline 1. & Work & 260 & 68,2 \\
2. & College & 47 & 12,3 \\
3. & Entrepreneur & 74 & 19,5 \\
\hline
\end{tabular}

Table 12 shows that most students have been able to determine the direction of the career to be taken, this is a good thing because VHS actually creates a workforce that is ready to be used in the industrial world. But no doubt there are some students who come from a background of economic higher level of education.

Career aspirations can be known from the categories in the career aspiration histogram variable in Figure 5, where the higher the results, the more students understand the career aspirations they have.

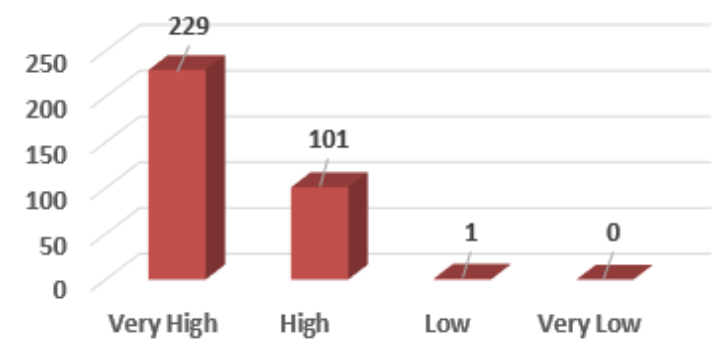

Figure 5. Histogram Graph of Career Aspiration Variable

\subsection{Test Requirements Analysis}

In order for the data to meet the requirements of multiple regression analysis and simple regression, it must meet the requirements of normality, linearity, multicollinearity, and together with capacity. An explanation of the results of the analysis requirements test is described as follows.

\subsubsection{Normality Test}

Normality test is carried out to find out whether the data distribution follows or approaches the normal distribution. Normality test on multivariate is actually very complex because it must be done on all variables together (Santoso, 2014). Data normality test in this study was carried out using the Kolmogorov Smirnov test. The criteria used in decision making are if the value of $p>0.05$ then the data is normally distributed, and vice versa if the value of $p<0.05$ then the data is not normally distributed. The results of the normality test of this research variable can be seen in Table 14 .

Table 14. Results of Variable Normality Testing

\begin{tabular}{ccc}
\hline Variable & $\mathbf{p}$ & Information \\
\hline Residual Variabel & 0,975 & Normal distribution \\
\hline
\end{tabular}

\subsubsection{Linearity Test}

Linearity test is performed to determine whether the data of each independent variable has a linear relationship with the dependent variable. Guidelines are used to determine linearity by looking at the results of the analysis in the Linearity lane. If the 


\subsubsection{Homosensity Test}

the relationship between the independent variable and the dependent variable is linear. Conversely, if the significance value in the Linearity row $\geq 0.05$ then the relationship between the independent variable and the dependent variable is not linear. The results of the linearity test can be seen in Table 15 .

Table 15. Results of Variable Linearity Tests

\begin{tabular}{|c|c|c|c|c|}
\hline \multirow{2}{*}{ No } & \multirow{2}{*}{ Variable } & \multicolumn{3}{|c|}{ Deviation from Linearity } \\
\hline & & $\mathbf{F}$ & Sig. & Inform. \\
\hline & Techno-logical & & & \\
\hline 1. & $\begin{array}{l}\text { Development-Career } \\
\text { Aspirations }\end{array}$ & 77,073 & 0,000 & Linear \\
\hline 2. & $\begin{array}{l}\text { Socio-Economic Status } \\
\text { - Career Aspirations }\end{array}$ & 7,008 & 0,004 & Linear \\
\hline 3. & $\begin{array}{l}\text { Career Information - } \\
\text { Career Aspirations }\end{array}$ & 98,153 & 0,000 & Linear \\
\hline 4. & $\begin{array}{l}\text { Learning Process - } \\
\text { Career Aspirations }\end{array}$ & 69,287 & 0,000 & Linear \\
\hline
\end{tabular}

\subsubsection{Multicollinearity Test}

Multicollinearity test is performed to find out whether there is a high correlation between the independent variables. Multicollinearity can be seen based on the magnitude of the correlation coefficient between independent variables. Sunyoto (2010: 97) states that multicollinearity occurs when the correlation coefficient between independent variables is more than or equal to $0.60(\mathrm{r} \geq 0.60)$, and vice versa it is said that there is no multicollinearity if the correlation coefficient between independent variables is less than 0.60 ( $\mathrm{r}$ $<0.60)$. The results of the correlation analysis between independent variables in this study are shown in Table 16.

Multicollinearity can also be seen from the magnitude of the Variance Influence Factor (VIF). If the Variance Influence Factor (VIF) value is <10, then there is no multicollinearity. The results of Multicollinearity testing through regression analysis obtained results like Table 17, where the results showed all $\mathrm{VIF}<10$, so there was no Multicollinearity.

Table 17. Results of Multicollinearity Testing with VIF

\begin{tabular}{llcc}
\hline No. & \multicolumn{1}{c}{ Variable } & VIF & Information \\
\hline 1. & Technological & 1,358 & \\
development & & There is no \\
2. & Socio-Economic Status & 1,037 & multicollinearity \\
3. & Career Information & 1,642 & \\
4. & Learning process & 1,724 & \\
\hline
\end{tabular}

Homosensityindicates a condition where the dependent variable has the same variance on all values of the independent variable. Homosacitytesting is performed by the Glejser test, which is by regressing the independent variable with the residue. If the regression coefficient is not significant $(p>0.05)$, it means that the data meets the together Alt capacity. The results of the homo-test capacity of the research data are shown in Table 18.

\subsection{Research Data Analysis}

Analysis of the data used in this study is a simple regression and multiple regression. Simple regression is used to find out:

\subsubsection{Effect of Technology Development on Career Aspirations of VHS Students in Kebumen Regency}

$$
\mathrm{Y}=24,986+0,550 \mathrm{X}_{1}
$$

The purpose of $\mathrm{Y}$ in the equation is the Career Aspirations of VHS Students in Kebumen and $\mathrm{X}_{1}$ Districts is Technology Development. Number 24,986 is the intercept or intersection point of the regression line on the $\mathrm{Y}$-axis when $\mathrm{X}_{1}=0$; while the number 0.550 is the regression coefficient of $X_{1}$.

\subsubsection{Effect of Socio-Economic Status on Career Aspirations of VHS Students in Kebumen Regency}

$$
\mathrm{Y}=37,151+0,211 \mathrm{X}_{2}
$$

The purpose of $\mathrm{Y}$ in the equation is the Career Aspirations of VHS Students in Kebumen Regency and $\mathrm{X}_{2}$ is the Socio-Economic Status. Figures 37.151 are intercepts or intersection points of the regression lines on the $\mathrm{Y}$ axis when $\mathrm{X}_{2}=0$; while the number 0.211 is the regression coefficient of $\mathrm{X}_{2}$

\subsubsection{Effect of Career Information on Career Aspirations of VHS Students in Kebumen Regency}

$$
\mathrm{Y}=25,900+0,358 \mathrm{X}_{3}
$$

The purpose of $\mathrm{Y}$ in the equation is the Career Aspirations of VHS Students in Kebumen Regency and $\mathrm{X}_{3}$ is Career Information. The number 25,900 is the intercept or intersection point of the regression line on the $\mathrm{Y}$-axis when $\mathrm{X}_{3}=0$; while the number 0.358 is the regression coefficient of $X_{3}$. 
3.4.4 Effects of Learning Processes on Career Aspirations of VHS Students in Kebumen Regency

$$
z=26,996+0,259 X_{4}
$$

The purpose of $\mathrm{Y}$ in the equation is the Career Aspirations of VHS Students in Kebumen Regency and $\mathrm{X}_{4}$ is the Learning Process. Figure 26.996 is the intercept or intersection point of the regression line on the $\mathrm{Y}$-axis when $\mathrm{X}_{4}=0$; while the number 0.259 is the regression coefficient of $\mathrm{X}_{4}$.

\subsubsection{Effects of Technology Development, Socio-Economic Status, Career Information and Learning Processes on Career Aspirations of VHS Students in Kebumen Regency}

$$
\begin{gathered}
\mathrm{Y}=14,214+0,299 \mathrm{X}_{1}+0,238 \mathrm{X}_{2}+0,198 \mathrm{X}_{3}+0,109 \\
\mathrm{X}_{4}
\end{gathered}
$$

The purpose of $\mathrm{Y}$ in the equation is the Career Aspirations of VHS Students in Kebumen Regency and $X_{1}$ is Technology Development, $X_{2}$ is SocioEconomic Status, $X_{3}$ is Career Information and $X_{4}$ is Learning Process. The number 14,214 is the intercept or intersection point of the regression line on the $\mathrm{Y}$-axis when $\mathrm{X}_{1}, \mathrm{X}_{2}, \mathrm{X}_{3}$ and $\mathrm{X}_{4}=0$; while the number 0.299 is the regression coefficient of $X_{1}$, the number 0.238 is the regression coefficient of $\mathrm{X}_{2}$, the number 0.198 is the regression coefficient of $\mathrm{X}_{3}$, and the number 0.109 is the regression coefficient of $\mathrm{X}_{4}$.

\subsection{RESEARCH DISCUSSION}

\subsubsection{Effect of Technology Development on Career Aspirations of VHS Students in Kebumen Regency}

Based on the results of the study, of 331 respondents it can be seen that as many as $74.9 \%$ stated that the development of technology had a very high influence; and $24.2 \%$ of respondents said that they had a high influence; while $0.6 \%$ stated that technological development has a low influence; and very low as much as $0.3 \%$. In addition, technological development variables have a partial correlation value of 0.429 . The coefficient of determination value is 0.184 which means that Technology Development influences VHS Career Aspirations in Kebumen Regency by $18.4 \%$.

Vocational education must be able to become a dynamic institution and be able to keep up with technological developments in the industrial world. The ability of institutions in introducing technology can be seen from students who are able to respond to technological developments. This shows that in order to be able to respond to technological developments, VHS requires efforts to provide students with a view of technology, not only the technology they face in school, but that develops outside of school. Based on the results of the discussion it is clearly proven that technological development influences students' career aspirations.

\subsubsection{Effect of Socio-Economic Status on Career Aspirations of VHS Students in Kebumen Regency}

Based on the results of the study, from 331 respondents it can be seen that as many as $8.2 \%$ stated that the socioeconomic status had a very high influence; and as many as $41.7 \%$ of respondents said they had a high influence; while $42.3 \%$ stated that socioeconomic status had a low influence; and very low as much as $7.9 \%$. In addition, the socioeconomic status variable has a partial correlation value of 0.143 . The coefficient of determination is 0.020 which means that the SocioEconomic Status influences VHS Career Aspirations in Kebumen Regency by $2 \%$.

Table 18. Results of Homosensity Capacity Testing

\begin{tabular}{lrrrrr}
\hline \multirow{2}{*}{ Model } & \multicolumn{2}{c}{ Unstandardized } & \multicolumn{2}{c}{$\begin{array}{c}\text { Standardized } \\
\text { Coefficients }\end{array}$} & Coefficients \\
& B & Std. Error & Beta & Sig. \\
\hline (Constant) & 2,241 & 1,358 & & 1,650 &, 100 \\
Technological development &, 019 &, 041 &, 030 &, 465 &, 642 \\
Socio-Economic Status &, 001 &, 041 &, 001 &, 024 &, 981 \\
Career Information &,- 051 &, 026 &,- 136 & $-1,926$ &, 055 \\
Learning process &, 033 &, 022 &, 109 & 1,508 &, 132 \\
\hline
\end{tabular}

a. Dependent Variable: RES2 
stated that the learning process had a very high effect; and as much as $37.16 \%$ of respondents said that they had a high influence; while as many as $1.21 \%$ stated the learning process had a low effect. In addition, technological development variables have a partial correlation value of 0.417 . The coefficient of determination is 0.174 which means that the Learning Process influences the VHS Career Aspirations in Kebumen Regency by $17.4 \%$.

Based on the results of the study it can be seen the influence of the learning process on student aspirations. In addition to the findings felt by students, among others: the inability of teachers to provide material and master classroom conditions, so students have not felt the maximum learning process. This shows that the learning process should pay attention to the elements that support it as explained. The concept of learning ideally produces students who are able to look critically at the world so that students' readiness for their career decisions is better prepared and thus will have an optimistic view of their future.

Based on the results of the study, from 331 respondents it can be seen that as many as $73 \%$ stated that career information has a very high influence; and $24.8 \%$ of respondents said that they had a high influence; while as many as $1.5 \%$ stated that career information has a low influence; and very low as much as $0.6 \%$. In addition, the career information variable has a partial correlation value of 0.472 . The coefficient of determination is 0.223 which means that Career Information affects the VHS Career Aspirations in Kebumen Regency by $22.3 \%$.

Suitability of information obtained by students will affect the way students look at the work to be decided. Career information plays a role in shaping the work readiness of VHS students in Kebumen Regency it is based on the career information variable questionnaire. Information about the world of work needed by students is information that must contain requirements so that students respond well. Based on the results of the analysis that students' career aspirations are determined by $22.3 \%$ of the working world information variables while the rest is influenced by other variables not included in this study.

\subsubsection{Effect of Learning Processes on Career Aspirations of VHS Students in Kebumen Regency}

Based on the results of the study, from 331 respondents it can be seen that as many as $61.63 \%$

\subsubsection{The Effect of Technology Development, Socio-Economic Status, Career Information and Learning Process on the Career Aspirations of VHS Students in Kebumen Regency}

Based on the results of the analysis of research data, as many as 331 VHS student respondents in Kebumen Regency, it was seen that the value of the multiple correlation coefficient in Technological Development, Economic Social Status, Career Information and Learning Process on Career Aspirations of VHS Students in Kebumen Regency was 0.565 . The coefficient of determination is 0.319 which means that Technology Development, SocioEconomic Status, Career Information and Learning Process on Career Aspirations of VHS Students in Kebumen Regency amounted to $31.9 \%$.

Research thatz shows the influence of technological developments, socioeconomic status, career information and learning processes on the career aspirations of VHS students in Kebumen Regency raises the belief that student education and career aspirations have relevance to determining the determining factors for pursuing educational and employment opportunities. So students who have good career aspirations will foster an attitude to seriously look for career information and will try to adjust their abilities and interests. This condition is a response of students to be able to achieve the desired 
work, so they are able to make the right career decisions in accordance with their career aspirations.

\section{CONCLUSIONS}

Based on the results of the study concluded as follows: (1) The development of technology affects the career aspirations of VHS students in Kebumen Regency with a contribution of $18.4 \%$; (2) The socioeconomic status of parents influences the career aspirations of VHS students with a contribution of $2 \%$; (3) Career information has an effect on students' career aspirations with a contribution of $22.3 \%$; (4) The learning process affects the career aspirations of students with a contribution of $17.4 \%$; and (5) Technological developments, socioeconomic status, career information, and learning processes together influence student career aspirations with a contribution of $31.9 \%$.

Based on the results of the research discussion and conclusions can be recommended as follows: (1) Schools should further improve the quality of teachers so that they can help students give views on technological developments and direct the future that students will face; (2) Schools present job information through specialized job fairs in accordance with good information criteria, so students are able to receive career information and prepare early on; (3) Providing career guidance to students through counselling guidance teachers and related parties so that students can decide what to do after graduation; (4) Parents should be able to pay attention to the child's development, both at home and at school by helping to direct the child's future and not impose his will on his future; and (5) It is expected that students will be able to prepare themselves to achieve the desired career expectations such as improving skills through learning in school or attending training.

\section{REFERENCES}

\footnotetext{
Administrator. (2012). Perlu SMK jurusan batu bara. Retrieved from http://www.penyelarasan.kemdikbud.go.id/content/de tail/304.html.

Berita Kebumen. (2012). Kebumen, kabupaten vokasi dengan 32.479 siswa SMK. Retrieved from http://www.berita kebumen.info/2012/06/ kebumenkabupa ten-vokasi-dengan-32479.html.

Depdiknas. (2003). Undang-Undang RI Nomor 20 Tahun 2003, Sistem Pendidikan Nasional.
}

Hurlock, E.B. (1973). Adolescent development. Tokyo: Mcgraw-HillKugakusha.

Juminardi. (2013). Kehidupan social ekonomi nelayan buruh di desa sungai bakau kecil kecamatan mempawah timur, Jurnal Ilmu Sosiatri, 2(2).

Merdeka. (2008). Daya serap lulusanVHS masih rendah. Retrieved from http://www.merdeka.com/ekonomi/ nasional/daya-serap-lulusan-VHS-masih-rendah110hf45.html.

Mubarok, H. (2012). Pengembangan layanan informasi karir berbasis ajaran Islam untuk meningkatkan aspirasi karir siswa di SMA Negeri 1 Brebes. Jurnal Bimbingan Konseling Universitas Negeri Semarang, $1,50-54$

Prosser \& Quigley. (1950). Vocational education in a democracy. Chicago: American Technical Society.

Quaglia, R.J \& Cobb, C.D. (1996). Toward a theory of student aspirations. Journal of Research in Rural Education, 12 (3), 127-132.

Santoso, S. (2014). Statistik multivariat (edisirevisi). Jakarta: PT. ElexMedia Komputindo.

Shertzer, et al. (1974). Fundamental of counseling. Boston: Houghton Mifflin Company.

Sugiyono. (2010). Metode penetilian pendidikan. Pendekatan, kuantitatif kualitatif dan R\&D. Bandung: CV Alfabeta

Sunyoto. (2010). Uji khi kuadrat \& regresi untuk penelitian. Yogyakarta: Graha Ilmu. 